\title{
Avicebron (Solomon Ibn Gabirol) and Berthold of Moosburg on Essential Causality
}

\author{
Alessandra Beccarisi \\ Università del Salento
}

As is well known, the theory of essential causality plays a central role in Berthold of Moosburg's commentary on Proclus' Elementatio theologica. Scholars have reconstructed its doctrinal genesis, seeing the dependencies on Albert the Great, Ulrich of Strassburg, and above all Dietrich of Freiberg. ${ }^{1}$ In the resulting picture, however, one piece is missing, which deserves to be considered, namely, the contribution of Avicebron's Fons vitae to the elaboration of the theory of essential causality. It is a contribution which, in quality and quantity, has no precedent amongst the philosophers traditionally considered to be Berthold of Moosburg's main sources and this influence, for reasons that will become clear shortly, can be considered unique to the Dominican philosopher.

It is Berthold who emphasizes the centrality of Avicebron, who not only appears among the philosophi famosi listed at the beginning of the commentary, but also three times in the Tabula contentorum ${ }^{2}$ that Berthold

1 E. King, Supersapientia. A Study of the Expositio super Elementationem theologicam Procli of Berthold von Moosburg, PhD diss. (University of Cambridge, 2016); M.R. Pagnoni-Sturlese, "A propos du néoplatonisme d'Albert le Grand: Aventures et mésaventures de quelques textes d'Albert dans le Commentaire sur Proclus de Berthold de Moosburg", in Archives de Philosophie 43(1980), p. 635-654; I. Zavattero, "Berthold of Moosburg”, in H. Lagerlund (ed.), Encyclopedia of Medieval Philosophy (Dordrecht: Springer, 2011); A. de Libera, "Résumés des conférences", in École Pratique des Hautes Études - Section des sciences religieuses. Annuaire 94(1985-1986), 1985, p. 499-519. I would like warmly thank Katie Reid for correcting this text and Evan King for his precious suggestions.

2 The Tabula contentorum in Expositione super Elementationem theologicam Procli is an index of 580 entries arranged in alphabetical order from Abditum mentis up to Zoegena. It is pre-

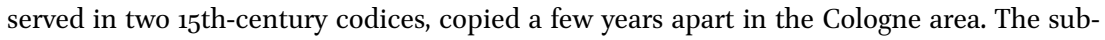
stantial agreement of the two codices in their structural elements makes it certain that the structure of the Tabula was already defined in their common exemplar and therefore comes from Berthold's project. A first edition of the Tabula was published by A. Beccarisi, Berthold of Moosburg, Tabula contentorum in Expositione super Elementationem theologicam Procli, ed. A. Beccarisi (Pisa: Scuola Normale Superiore, 2000). The critical edition of the Elementatio theologica Procli is now complete: Berthold of Moosburg, Expositio super Elementationem theologicam Procli, 8 vols. (Hamburg: Meiner, 1984-2014). 
adds to his work. The name of Avicebron appears under the letter A as follows: ${ }^{3}$

\author{
Avencebrol \\ Liber Fons vite frequenter allegatur \\ De unitione secundum eum 4 (A). Item condiciones unius. \\ Condiciones derivantis esse aliis secundum eundem 18.
}

\title{
Avicula
}

199 Quod sicut avicula in aere et navicula in mari sic terra in universo secundum Avencebrol libro Fons vite.

The contribution of Avicebron in Prop. 18 is indeed remarkable for better defining the characteristics and conditions of what gives being to lower entities, a topic explicitly linked to that of essential causality ("De primo sciendum quod derivans esse aliis quodcumque, quod etiam necessario est causa essentialis [...]"). ${ }^{4}$ Berthold deals specifically with this doctrine in Prop. 172, as declared programmatically in the Tabula.$^{5}$

\section{Causa}

[...] Cause essentialis triplex condicio 172. Triplex effectum prehabitio. Quod omnis intellectus in actu habet rationem cause essentialis. Cause efficientes sunt in triplici differentia.

\section{CAUSA ESSENTIALIS}

De hac et eius multiplici condicione 172.

It is not surprising, therefore, that in Prop. 172 one also finds an extensive use of Avicebron's Fons vitae which Berthold quotes next to Dietrich's De cognitione entium separatorum. ${ }^{6}$ In my view, it is significant that, among Dietrich's many works, Berthold chooses the De cognitione entium separatorum to explain this point. As is well known, this is a late work, which can be considered a summa

3 Berthold of Moosburg, Tabula, p. 23, 507-515.

4 Berthold of Moosburg, Expositio, 18D, p. 52, l. 291-292.

5 Berthold of Moosburg, Tabula, p. 31, l. 100-p. 32, l. 106.

6 Dietrich of Freiberg, De cognitionum entium separatorum et maxime animarum separatarum, ed. H. Steffan, in Dietrich of Freiberg, Schriften zur Naturphilosophie und Metaphysik, eds J.-D. Cavigioli et al. (Hamburg: Meiner, 1983), p. 151-26o. 
of Dietrich's theory of essential causality. ${ }^{7}$ It is a work, however, which does not emphasize the agent intellect as an essential cause and in which Dietrich is somewhat cautious about the existence of celestial souls.

It is also important to note that in none of these contexts is Avicebron's contribution transmitted to Berthold through Thomas of York's Sapientiale, which also uses the Fons vitae extensively. ${ }^{8}$

In order to understand how Berthold combines Dietrich's authority with Avicebron's on the question of essential causality, I will proceed as follows: in the first part I will present Avicebron's doctrine on the relationship between God and creatures, and then move on in the second section to describe the essential points of Dietrich's De cognitione entium separatorum. Finally, in the third part I will present the synthesis offered by Berthold of Moosburg, focusing on his commentary on Propositions 18 and 172 of Proclus' Elementatio theologica.

My aim is to show the consonance between the metaphysics of fluxus developed by Avicebron based on the overflowing of forms, and the doctrine of essential causality theorised by Dietrich of Freiberg.

\section{1 \\ Avicebron on the Notions of fluxus and Will}

In the medieval Latin West, the name Avicebron was not known before the middle of the 12th century. Around 1150, in Toledo, Dominicus Gundissalinus and Johannes Hispanus translated the Fonsvitae into Latin from an Arabic original that is now lost. ${ }^{9}$ Avicebron or Avencebrol, as he was known to Christian authors, is the author of a philosophical summa in five books, published at

7 K. Flasch, "Einleitung", in Dietrich of Freiberg, Schriften zur Naturphilosophie und Metaphysik, p. XV-XXXI, in particular p. XXVI; T. Suarez-Nani, "Substances séparées, intelligences et anges chez Thierry de Freiberg", in K.-H. Kandler, B. Mojsisch, F.-B. Stammkötter (eds), Dietrich von Freiberg. Neue Perspektiven seiner Philosophie, Theologie und Naturwissenschaft (Amsterdam: Grüner, 1999), p. 49-67, in particular p. 52-57; B. Mojsisch, “Causa essentialis bei Dietrich von Freiberg und Meister Eckhart”, in K. Flasch (ed.), Von Meister Dietrich zu Meister Eckhart (Hamburg: Meiner 1984), p. 106-114.

8 Thanks to the excellent work of Fiorella Retucci, who in a recent article highlighted Berthold's considerable debts to the Sapientiale, it is possible "to isolate" the original interventions of the Dominican. Cf. F. Retucci, "Magister Thomas Anglicus minor: Tommaso di York fonte della Expositio super Elementationem theologicam Procli", in Quaderni di Noctua 5(2020), p. 1-41.

9 S. Pessin, Solomon Ibn Gabirol (Avicebron), in Stanford Encyclopedia of Philosophy https:// plato.stanford.edu/entries/ibn-gabirol/. [accessed October 26, 2020] 
the end of the 19th century by Clemens Baeumker. ${ }^{10}$ This work is a dialogue between a teacher and a pupil, aiming to teach the way human beings can realize their nature and fulfil their purpose, i.e. achieve their happiness. The aim of a human being, as it emerges at the end of the fifth book, is to know the external world and, going back from the most "contracted" determinations to the simplest, to bring the human back to the unity of its origin, which is the source of life. Studying the essence of simple substances, the disciple is led into the amoenitatibus floridis ${ }^{11}$ of the intelligible reality, and therefore has a chance to rise from the visible to the invisible, from the composite to the simple, from the effect to the cause.

Even if the Fons vitae completely lacks explicit quotations (with the exception of those linked to Sacred Scripture), scholars now agree that it is a grandiose synthesis, attempting to harmonize Neoplatonic metaphysics with the creationist belief common to Jews, Christians, and Muslims. ${ }^{12}$ In Latin Scholasticism, Avicebron's thought was often reduced to a few key issues: the hylomorphic conception of the totality of reality, the doctrine of the plurality of substantial forms, the existence of rationes seminales in matter, and the question of intelligible matter. There are, however, two important exceptions: Thomas of York, who in his Sapientiale abundantly cites the Fons vitae, and Berthold of Moosburg. Berthold's magnumopus is perhaps the most Gabirolean of all scholastic works. ${ }^{13}$ In his commentary on Proclus' Elementatio theologica, not only does Berthold show that he knows the Fons vitae firsthand, but also that he greatly appreciates Avicebron's synthesis, which stands in sharp contrast to the absolutely negative attitude of Albert the Great. ${ }^{14}$ In this respect, Berthold follows in the footsteps of Meister Eckhart, who also shows great

10 Avicebron (Ibn Gabirol), Fons vitae. Translationem ex Arabico in Latinum, ed. C. Baeumker (Münster: Aschendorff, 1892-1895).

11 Avicebron, Fons vitae, lib. v, c. 57, p. 205, 1. 8.

12 B. McGinn, "Sapientia Judaeorum: the Role of Jewish Philosophers in Some Scholastic Thinkers", in R.J. Bast, A.C. Gow (eds), Continuity and Change. The Harvest of Late Medieval and Reformation History (Leiden: Brill, 200o), p. 206-228, in particular p. 221225; M. Benedetto, Saggio introduttivo, in Avicebron, Fonte della vita, ed. M. Benedetto (Milano: Bompiani, 2007), p. 11-197, in particular p. 29-68; N. Bray, "Eckhart e la riforma filosofica dell'umiltà cristiana", in Giornale critico della filosofia italiana, forthcoming. I would like to thank her for having made unpublished materials available to me.

13 McGinn, “Sapientia iudeorum", p. 226; Benedetto, Saggio, p. 193-197; King, Supersapientia, p. 189 .

14 Bray, "Magis videtur fuisse Stoicus. La ricezione di Avicebron in Alberto il Grande", in A. Beccarisi, A. Palazzo (eds), Flumen Sapientiae, Studi sul pensiero medievale (Roma: Aracne Editrice, 2019), p. 69-87; McGinn, "Sapientia iudeorum", p. 216-217; Benedetto, Saggio, p. $173^{-175}$. 
interest in Avicebron..$^{15}$ Among the many themes that attract Berthold's attention, two in particular are considered relevant, so much so that they are mentioned in his Tabula: the theme of the derivation of entities from others and the associated theme of essential causality. In the first case, Berthold uses the concepts of largitas and desiderium, in the second that of the flow of radii et vires from the simple substances. Let us look at these in detail, before moving onto Berthold's use of them.

Avicebron conceives of God in tripartite terms: as First Essence (which is inaccessible), Will (understood as an intermediary between God and Creation, but also as the productive aspect of God) and active and manifest Wisdom. In this way we can know God only through the manifestation of his Will and Wisdom in the ordained structure of entities in the universe (that is, through the things he does and sustains, and in particular, through the wisdom revealed by them). These entities are called by Avicebron simplices substantiae, by which he means the Neoplatonic Universal Intellect and the Soul (or Souls). These simple substances (exemplified in the simple substance of the Intellect, that is the highest created manifestation of God's creative Will and Wisdom) are theorized as intermediaries between God and the lowest substance. ${ }^{16}$ In this way Avicebron takes up the Neoplatonic formula of the self-diffusive Good which in the Fons vitae coincides with the voluntas Dei - while preserving at the same time God's absolute transcendence, because, according to Avicebron, God does not give Himself, but what He has apud se, that is, His forma universalis, which is an agens necessario:

Factor primus excelsus et sanctus largus est ex eo, quod habet apud se, ideo omne, quod est ab eo, effluens est. Et quia fons esse primus largitor est formae, quae est apud se, idcirco non est prohibens, quin effluat; et hic fons est coercens omne, quod est, ambiens et comprehendens. Unde necesse est, ut quaecumque substantiae sunt, sint oboedientes actioni eius et sequentes eum in dando suas formas et largiendo suas vires, quamdiu invenerint materiam paratam ad recipiendum haec. Fluxus

15 N. Bray, "Eckhart e la riforma filosofica dell'umiltà"; A. Palazzo, "Eckhart's Islamic and Jewish Sources: Avicenna, Avicebron, and Averroes", in J.M. Hackett (ed.), A Companion to Meister Eckhart (Leiden: Brill, 2013), p. 253-298, in particular p. 271-281; F. Brunner, "Maître Eckhart et Avicébron", in J. Jolivet, Z. Kaluza, A. de Libera (eds), Lectionum Varietates. Hommage à Paul Vignaux (1904-1987) (Paris: Vrin, 1991), p. 133-154, in particular p. 15o; B. McGinn, "Ibn Gabirol: The Sage among the Schoolmen", in L.E. Goodman (ed.), Neoplatonism and Jewish Thought (Albany, NY: sunY Press, 1992), p. 77-109, in particular 96-97.

16 Cf. Pessin, Solomon Ibn Gabirol (Avicebron) [accessed October 26, 2020]. 
autem substantiarum intelligitur motus et desiderium earum circa dandi actionem, in quo imitantur factorem primum. Sed sunt diversae in hoc secundum perfectionem earum et imperfectionem, quia earum aliae fluunt in non tempore, aliae fluunt in tempore, et proportio quarumlibet altiorum substantiarum ad inferiores in dando fluxum talis est, qualis proportio primi factoris ad altiores substantias et inferiores ad influendum super illas, quamvis fluxus earum in unoquoque modo est diversus. Similiter etiam comparatio altiorum substantiarum ad factorem primum in recipiendo ab ipso talis est, qualis est inferiorum ad altiores in recipiendo ab ipsis. Et omnino prima influxio, quae est complectens omnes substantias, ipsa fecit necesse, ut aliae substantiarum influerent aliis. ${ }^{17}$

This action, which proceeds from the first Creator through the mediation of the Will, is transmitted to the inferior entities that wish to imitate the perfection of the first Creator. This connection of generosity and desire constitutes the flow which, according to Avicebron, holds the whole universe together, making it intelligible and comprehensible (Fons vitae, III.25, p. 413). The simple substance, which receives the universal form from the Creator, cannot imprint on what is composite anything that is not already in its essence. Otherwise, a created substance would create from nothing, and thus would appropriate what is proper to the Creator. The problem, then, is to relate the multiplicity and extension of sensitive forms to the purity and simplicity of that from which they derive. Therefore, Avicebron argues, it is not the substance that flows (because in that case we would have an identity of essence at every level of reality, without hierarchical order); rather, only the radii et vires of the substances are communicated.

Just as the first Creator gives only what is apud se, likewise spiritual substances give to inferior realities only what is near them. As is clearly stated in Fons vitae III.52, this means that they do not give their essences, but their perfections, their radii and vires:

Essentiae substantiarum simplicium non sunt defluxae, sed vires earum et radii haec sunt, quae defluunt et effunduntur eo, quod essentiae uniuscuiusque harum substantiarum finitae sunt et terminatae et non extensae usque in infinitum, sed radii earum fluunt ab illis et excedunt terminos suos et limites propter continentiam earum sub primo fluxu, qui effluit a voluntate, scilicet prime boni, sicut lumen, quod effluit a sole in aerem, quia hoc lumen excedit terminos solis et extenditur per aerem, 
et sicut vis animalis effluit a virtute rationali, cuius sedes est cerebrum, et in nervos et lacertos, quia haec virtus est penetrans et diffusa per omnes partes corporis, et substantia animae in se non est diffusa neque extensa, similiter quaelibet substantiarum simplicium extendit radium et lumen suum et diffundit in id, quod est inferius eo, et tamen substantia in hoc retinet ordinem suum et non excedit finem suum. ${ }^{18}$

According to Fernand Brunner, ${ }^{19}$ the emanation of creatures is as it is precisely because it has a relationship of identity and otherness with respect to its first Cause. All things differ from the Cause since they are not the Cause, and yet all things are identical to the Cause because they depend on it. The first Creator never degrades into its effect, because it never comes out of itself; insofar as it remains in itself, it affirms itself, projecting its image (the Will) which is not itself but which is nevertheless from itself.

Another important element involved in the process of emanation is undoubtedly the Will, whose role is clarified especially in the fifth book of the Fons vitae ${ }^{20}$ but which Avicebron also mentions in previous books. The Will is the link between God and creation, a first hypostasis of the divinity that is - at the same time - a hypostasis external to God (but other than the Intellect) and an aspect of the divine essence. The Will secundum essentiam coincides with God and as God is infinite and indefinable, but secundum effectum is different from him, because it is made finite and accessible by his action. The Will is responsible for the order of reality: its being fortior apud deum quam est longius ab eo proceeds in parallel with the gradual passage from the purity to corporeality of entities, although degradation is a function of the essence of what receives it, that is, of the matter in which it is placed. The light of the Will spreads everywhere with the same intensity; it is matter which then determines the greater or lesser opacity of the various substances that receive it. ${ }^{21}$ Although Avicebron does not provide a thematic discussion of the Will of God, the role assigned to it within Fons vitae is far from marginal: in addition to being the limit of human knowledge, the Will functions as a connecting element between God and creation, transmitting to the latter what it receives from the former. Yet this conception of the Will takes hold only to a limited extent in Latin culture, which is attracted more than anything else by the doctrine of

18 Avicebron, Fons vitae, lib. III, c. 52, p. 196, l. 5-20.

19 F. Brunner, "Création et emanation. Fragment de philosophie comparée", in F. Brunner, Métaphysique d'Ibn Gabirol et de la tradition platonicienne (Aldershot: Ashgate / Variorum, 1997), p. 39-40.

20 Avicebron, Fons vitae, lib. v, c. 37, p. 663.

21 Benedetto, Saggio, p. 116. 
universal hylomorphism, although there are rare occasions in which the name of Avicebron is connected with the theme of the Will. One of the exceptions is precisely that of Berthold, as we shall see shortly.

To summarise so far: the purpose of the human being is to achieve happiness, that is, to know the universe in which he is inserted as a substance. As a substance, the human being is also subject to the law of flow, which transmits the divine vis from the first Cause to the lower realities. This process of emanation occurs thanks to the largitas of the first Creator and the desire of simple substances to imitate the factor primus. Between God and his creation, however, there is an intermediary, the Will of God, which, while coinciding with him, is at the same time his productive side, so to speak, and therefore other than him. In this way, a dynamic of identity and difference is established in all degrees of being: identity is guaranteed by the flowing of radii et vires that are communicated by the Will to the inferior realities, and difference is guaranteed because what flows is not the same essence, but rather the qualities of it. It is therefore not surprising that Berthold shows great interest in Avicebron's solution to the problem of the One and many, as we shall see in the third section of this paper. For now, I will proceed to a quick overview of the other source used by Berthold in connection with the concept of essential causality: the treatise De cognitione entium separatorum by Dietrich of Freiberg.

\section{Dietrich of Freiberg and Essential Causality}

Much has been written about essential causality in Dietrich of Freiberg. ${ }^{22}$ This section will not, therefore, add anything to what has already been effectively demonstrated. Its purpose is merely a general presentation of what Dietrich says about essential causality in De cognitione entium separatorum. The choice of this treatise is determined by the fact that Berthold himself in Prop.

B. Mojsisch, "Die Theorie des Intellekts bei Berthold von Moosburg. Zur Proklosrezeption im Mittelalter", in Th. Kobusch, B. Mojsisch, O. Summerell (eds), Selbst - Singularität Subjektivität: Vom Neuplatonismus zum Deutschen Idealismus (Amsterdam: Grüner, 2002), p. 175-184; B. Mojsisch, "Causa essentialis bei Dietrich von Freiberg und Meister Eckhart", in K. Flasch (ed.), Von Meister Dietrich zu Meister Eckhart (Hamburg: Meiner, 1984), p. 106114; M.R. Pagnoni-Sturlese, "Filosofia della natura e filosofia dell'intelletto in Teodorico di Freiberg e Bertoldo di Moosburg", in K. Flasch (ed.), Von Meister Dietrich zu Meister Eckhart (Hamburg: Meiner, 1984), p. 115-127; M.R. Pagnoni-Sturlese, "À propos du néoplatonisme d'Albert le Grand: Aventures et mésaventures de quelques textes d'Albert dans le Commentaire sur Proclus de Berthold de Moosburg", in Archives de Philosophie 43(1980), p. 635-654; K. Flasch, Dietrich von Freiberg. Philosophie, Theologie, Naturforschung um 1300 (Frankfurt: Klostermann, 2007), p. 201, 534. 
172 - explicitly dedicated to the theme of essential causality - extensively quotes this treatise.

According to the schema provided by Proclus' Elementatio theologica, Dietrich of Freiberg states that the structure of reality is organized in four hierarchical orders, four maneries entium. Although Dietrich addresses this issue in many of his works, it is specifically at the beginning of De cognitione entium separatorum that one finds a complete formulation of this structure: God represents the summit of reality, followed by the intelligences and then the celestial souls; then come the angels and lastly human souls. God occupies the summit of the hierarchy of reality. He is indeed the first cause of the totality of things by the mode of creation, and his perfection exceeds all other perfection. God is intellect in essence; he is perfect unity and simplicity.

The second degree of being proceeds immediately from God. These are the intelligences, purely intellectual substances or intellects by essence - because of their proximity to the first principle, in each of them the totality of the created universe is reflected and shines forth. Each intelligence proceeds from another through a mode of essential causality conferred upon it by God, but is a mode of production inferior to creation, for it presupposes the creative activity of the first principle. Dietrich makes an important remark regarding these intellectual substances; their existence is posited in relation to the order of nature and according to the opinion of the philosophers, which can be accepted or rejected as long as the existence of such substances is not enshrined in Sacred Scripture, where no mention is made of them (“[...] si admittatur positio philosophorum eo, quod Scriptura sancta de eis non loquitur [...]"). ${ }^{23}$

The same consideration also applies to the third degree of realities posited by the philosophers in the order of nature, the celestial souls ("Ex his tertio loco secundum philosophos procedunt quaedam substantiae intellectuales, quas animas caelorum dicunt"). ${ }^{24}$ Just like the intelligences, celestial souls are purely intellectual substances, that is to say, intellects by essence, but of a perfection inferior to those that precede them: firstly, because they are produced by the intelligences and therefore do not proceed directly from the first principle, and secondly, because they are ordered to bodies, that is to say, to the celestial bodies whose act and form they are. At the fourth level of the hierarchy are the angels: although they are purely immaterial realities, the angels are spiritual substances and are no longer intellectus per essentiam. In Dietrich's conception this means that angels are not pure and simple essences, because

23 Dietrich of Freiberg, De cognitione, 1.1-3, p. 168, 1. 34-51.

24 Dietrich of Freiberg, De cognitione, 1.4, p. 168, l. 52-p. 169, l. 63. 
their faculties and operations differ from their substances: therefore, angels are composed, individualized realities, and their action is no longer essential.

Finally, in the fifth and last degree, there are human souls, whether they are considered according to their union with the body that they animate or according to their separation from it. As with angels, so also with human souls, but to a still greater extent, their faculties and operations differ from their substances. The criterion of this hierarchy is action through a thing's own essence and therefore the exercise of an essential causality. Only this kind of causality is capable of ensuring continuity between the different levels of reality, in order to guarantee its homogeneity and unity. But what is an essential cause? First of all, according to Dietrich, the essential cause contains in itself more eminently its caused and the being of its effect ("necessarium est ipsam habere causatum suum et esse causatum suum nobiliore et eminentiore et perfectiore modo, quam ipsum causatum sit in se ipso secundum propriam naturam"). ${ }^{25}$ He then enumerates five properties that are required for a cause to be defined as essential: it must be 1) substantia, 2) substantia viva, 3) substantia viva essentialiter. The life which the essential cause lives is 4) vita intellectualis and therefore is proper to 5) intellectus in actu per essentiam.

Dietrich clearly states that, of the five levels of reality listed above, only three can be said to be essential causes: God, intelligences, and celestial souls ("Et ista quinque conveniunt substantiis separatis, scilicet Deo et intelligentiis et his, quasi animas caelorum vocant"). ${ }^{26}$ Three elements should be kept in mind. Firstly, according to Dietrich, God and celestial souls are essential causes. Secondly, throughout the treatise, Dietrich keeps a prudent distance from the vexata quaestio of the animation of the heavens. He presents it as an idea of the philosophers, which can be rejected or accepted. ${ }^{27}$ Thirdly, essential causality is explained by Dietrich as an inner activity, which institutes a homogeneous unity that communicates the divine creative activity, which is the essential cause par excellence. In Dietrich's universe the essential causes are therefore necessary mediations: they exert an intermediate causality that ensures continuity, homogeneity, order in the totality of reality and, therefore, guarantees intelligibility. Causae essentiales exclusively concern intellects by essence, which are the only entities free of all composition and are vivae per se.

25 Dietrich of Freiberg, De cognitione, 22.5, p. 186, 1. 84-9o.

26 Dietrich of Freiberg, De cognitione, 23.1-6, p. 186, l. 93-p. 187, l. 110.

27 On this topic cf. L. Sturlese, "Il De animatione caeli di Teodorico di Freiberg", in R. Creytens, P. Künzle (eds), Xenia medii aevi historiam illustrantia oblata Thomae Kaeppeli O.P. (Roma: Edizioni di storia e letteratura, 1978), p. 175-247; Suarez-Nani, Substances séparées, p. $5^{2}$. 
Now, what is living is distinguished from what is not living by the fact that living being contains its principle of motion within itself, according to which each part moves another. In De intellectu et intellegibili Dietrich interprets this purely experimental datum as a transfusio of one part on the other, which causes an overflow to the outside. Thus, all overflow presupposes an inner activity.

Sicut autem dictum est de corporibus, ita se habet de animabus seu animatis, videlicet quod necessarium est inveniri in eis quoad suas partes quandam transfusionem, qua una pars fluat in aliam, quo redundet in extra. Quod non solum per experientiam patet tam in vivis perfectis, videlicet in motu cordis, arteriarum, pulmonis et pectoris et ceteris talibus, verum etiam in imperfectis ut in plantis et conchyliis, ut in ostreis et ceteris talibus, non solum, inquam, hoc habetur per experientiam, sed etiam ex propria ratione vivi inquantum vivum, quia vivum differt a non vivo in habendo in se principium sui motus, quo una pars movet aliam. ${ }^{28}$

The essential order so described, which links the different orders of reality, is thus the result of a model that Dietrich derives from the observations of the structure of physical and living beings. The intellectus in actu per essentiam are therefore entities living intellectually because of an interiorem transfusionem:

Sed hoc video inquirendum, quomodo in istis intellectibus inveniatur aliqua interior transfusio, quo aliquid fluat in aliud, quo etiam in eis inveniantur principia activa, et praecipue in eis, qui sunt intellectus per essentiam semper in actu. ${ }^{29}$

This is why the rationality of the universe rests on its unity: this unity is not that of a disordered mass but results from the links that join the different components of the universe to each other. Essential causes are thus necessary for the cohesion of the universe according to Dietrich's view, and this causality can only be exercised by intellects essentially in act, that is, by intelligences of the Neoplatonic type. Dietrich thus identifies with Proclus and the Liber de causis $^{30}$ the One and the Good, which refers to the relationship between the

28 Dietrich of Freiberg, De intellectu et intellegibili in Dietrich of Freiberg, Schriften zur Intellekttheorie, ed. B. Mojsisch (Hamburg: Meiner, 1977), p. 131-210, here I.6.1, p. 139, l. 88-p. 140, l. 10.

29 Dietrich of Freiberg, De intellectu, I.8.1, p. 141, 1. 46-49.

30 Cf. D. Calma, Le poids de la citation: Étude sur les sources arabes et grecques dans l'oeuvre de Dietrich de Freiberg (Freiburg: Academic Press, 2011). 
origin and the originated. Being moves from the One as origin to the Good as destination in a cycle that shows origin and destination to be identical. In all of the levels of being mentioned above, being necessarily flows into something outside of itself, because otherwise it would be redundant and futile in nature, as Dietrich claims in De intellectu. ${ }^{31}$

Dietrich's doctrine on essential causality does however have a limit: it seems to establish a relationship of identity and difference between the various parts that make up the structure of the universe (the famous formula "identical in essence, but different in being"), but in fact it does not explain how this happens - what the process is that grounds essential causality.

Two important issues remain to be clarified: In what sense must the statement "the cause contains its caused in a more eminent and noble way" be understood? Could this not lead to an identity of the levels of being, which would thereby nullify the hierarchical order?

\section{Berthold of Moosburg on Essential Causality: Prop. 18}

As recently summed up by Irene Zavattero, ${ }^{32}$ Berthold explains the structure of the Proclean cosmos by means of "the fluxus-doctrine" of Albert the Great and Ulrich of Strassburg. ${ }^{33}$ In order to explain how this fluxus takes place, Berthold resorts to Dietrich of Freiberg's theory of essential causality. As mentioned at the beginning of this paper, however, Berthold quotes another authority to support his interpretation of the essential cause, namely the Fons vitae of Avicebron, whose use goes far beyond the merely doxographical. This clearly emerges from his Tabula contentorum where, under the entry "Avencebrol", he recalls the theme of the bestowal of being and the ontological status of the giver of being relative to lower realities - a theme that he explicitly connects to essential causality. The proposition to which Berthold is referring in his Tabula

31 Dietrich of Freiberg, De intellectu, I.10.2, p. 143, 1. 6-11: Ex praemissis colligitur substantiam illam, et hoc omnem talem, quae est intellectus per essentiam semper in actu, habere in se virtutem principii activi, qua agit aliquid extra se in aliud. Alioquin esset frustra in natura. Frustra enim est, quod destituitur proprio fine secundum Philosophum in II Physicorum. Natura autem nihil agit frustra, quia, sicut non deficit in necessariis, ita non abundat in superfluis.

32 I. Zavattero, "Berthold of Moosburg", in H. Lagerlund (ed.), Encyclopedia of Medieval Philosophy (Dordrecht: Springer, 2011), p. 163-165.

33 Tommaso Ferro is dedicating his doctoral work to the theme of essential causality in Ulrich of Strassburg under my supervision and that of Prof. Andreas Speer. Cf. also King, Supersapientia, p. 155, 168-169. 
is Prop. 18, which states: "Omne derivans esse aliis ipsum prime est hoc, quod tradit recipientibus derivationem". ${ }^{34}$ By invoking many authorities Berthold demonstrates in his commentary the primacy of what gives being over what receives it. He cites Avicebron verbatim and extensively to demonstrate the conditions (the status) of the giver of being, the necessity of simple substances between the first cause and lower realities, and the nature of the action performed by the different levels of reality on each other. Berthold interprets the connection of each derivans esse in terms of essential causality, carried out by simple substances, which, as we have seen, share the divine virtus with lower, composite realities.

Berthold first enumerates the features of every derivans esse: it must be (necessarium est) "bonum, unum, perfectum, plenum, simplex, forte sive potens, subtile, spirituale, luminosum et quodammodo infinitus seu interminabilis essentiae". For the first four condiciones, Berthold summons the authorities of Dionysius, Proclus, and Macrobius, while to describe the remaining attributes he quotes a very long passage from the third book of the Fons vitae, in which Avicebron provides a demonstration of the existence of the simple substances according to the action performed by these substances on each other. We have seen, indeed, that simple substances share their forms both out of the desire to imitate the largitas of the primary cause and from their intrinsic constitution (nature), because the stronger and more subtle the agent is, the more incisive and penetrating its action. Avicebron's demonstration is based on the observation that composed substances such as quantitas et figura do not have the capacity to "influence" because of their weakness and coarseness. It can be deduced, therefore, that simple substances have the capacity to communicate their forms precisely because they are simpler and more luminous than composite entities. If this is true, how much subtler and stronger must be the virtus Dei that spreads and penetrates everywhere. Berthold therefore fully agrees with Avicebron, who believes, as we have seen in the first part, that it is not God himself who flows, but rather, his virtus, or universal form.

This dynamic, described bottom-up as a progressive simplification of entities, implies that everything is simpler, more subtle and luminous in itself than in the composite entities to which it is communicated. Simple substances, therefore, accept the forms (which they then transmit to what is below) in a purer way than they are in composite substances. 
Quinta condicio cum sequentibus patet per Avencebrol libro III cap. 15, ubi dicit: “[...] Effluxio enim est ex impulsu, impulsus autem ex vi; signum autem, quod vis et subtilitas faciunt influxum, est hoc, quod quantitas et figura non imprimunt suum simile in obstans, cum potens fuerit recipere; et hoc non est nisi propter debilitatem quantitatis et grossitudinem eius ad penetrandum. Similiter dicendum de accidente, quia, quo fuerit fortius, subtilius et luminosius, erit penetrabilius. Conficiemus ergo ex his sex propositionibus hoc, scilicet quod substantiae simplices necesse est, ut dent se ipsas et conferant suas formas. Et etiam quia hoc, quod vires et radii, qui effluunt de corpore, sunt spirituales, signum est, quoniam effluere debent etiam substantiae spirituales. Et etiam quia, cum nos invenimus substantiam corpoream prohibitam ad conferendum se propter crassitatem quantitatis et tenebrositatem eius, et tamen quantitas confert umbram suam corporibus, quae opposita sunt, adeo quod, cum invenerit corpus lucidum ut speculum, dat ei formam suam, quanto magis necessarium est secundum hanc considerationem, ut substantia spiritualis, quae est immunis a quantitate, sit effluens suam essentiam et virtutem et lumen suum? ... Quanto enim fuerint subtiliores, fortiores et meliores, tanto magis aptae sunt ad agendum et conferendum se et sua". Et infra: "Et cum attenderis, quod essentia substantiae simplicis non habet finem, et attenderis vim eius, et cogitaveris penetrabilitatem eius in rem contra positam, quae parata est recipere eam, et comparaveris inter eam et substantiam corpoream, invenies substantiam corpoream non potentem esse ubique et debilem ad penetrandum res, et invenies substantiam simplicem, hoc est substantiam animae universalis, diffusam per totum mundum et sustinentem illum in se propter subtilitatem et simplicitatem suam; et sic invenies substantiam intelligentiae universalis diffusam per totum mundum et penetrantem illum. Causa autem huius est subtilitas substantiarum ambarum et vis et lumen earum; et propter hoc fuit substantia intelligentiae infusa et penetrans interiora rerum. Quanto magis ergo secundum hanc considerationem debet esse virtus Dei sancti penetrans omnia, existens in omnibus, agens in omnibus sine tempore!"

Ex dictis Avencebrol colligitur evidenter omne derivans esse aliis esse simplex, forte, subtile, spirituale, luminosum et quodammodo infinitum et interminabilis essentiae. ${ }^{35}$ 
From the passage from the Fons vitae, which Berthold quotes literally and extensively, it is clear that he shares two of Avicebron's aforementioned positions: 1) both the simple substances and the first Creator share only what is apud se, namely, the virtus, radii and vires, and not the same essence. 2) The activity of God and of the simple substances, however, extends throughout the universe (penetrans omnia, existens in omnibus, agens in omnibus) due to their subtility and simplicity, which explains the mechanics of essential causality.

Once the conditions of each derivans esse aliis have been defined, it necessarily follows that it is an essential cause, as Berthold clearly states in section 18D: "De primo sciendum, quod derivans esse aliis quodcumque, quod etiam necessario est causa essentialis [...]". As such, it spreads a univocal intention through all its participants. But although this intention exists in the determined entity, that entity does not lose its intrinsic nature. It remains identical in its determinations, varying only in the mode of being of the various realities that constitute the universe. This, as is well known, is the law of essential causality formulated by Dietrich of Freiberg in the treatise De intellectu et intelligibili, where he establishes a difference between the relationship of causecaused and that of determinable-determined. Unlike a cause in the caused (effect), which "recedes from its proper intelligibility":

Non sic se habent ad invicem determinabile et id, in quod fit determinatio, quia talia non habent se ad invicem ex additione secundum essentiam, quamvis numerentur secundum esse, nec ipsum determinabile existens in determinato recedit et cadit a sua propria ratione, sed idem et eiusdem rationis et proprietatis per essentiam manet in tali determinatione, sed solum variatur secundum esse, et idem et eiusdem rationis per essentiam manet sub diverso modo essendi. ${ }^{36}$

Because of essential causality, every order of reality is always immediately intelligible, in that the essence is present in the determined, which guarantees the unity and intelligibility of the entire universe and, at the same time, ensures the possibility for the human being to return, through knowledge, to its origin.

In support of Dietrich's position, Berthold cites, once again, long passages from the Fons vitae, in order to demonstrate the following points: intellectual apprehension occurs by similarity, and every derivans esse aliis knows the spirituality of things (their essence); every derivans esse aliis has knowledge of all

36 Dietrich of Freiberg, De intellectu, III.21.3, p. 194, l. 111-117. Cf. Berthold of Moosburg, Expositio, 18D, p. 53, l. 342-354. 
things that derive from it, and knowledge is nothing more than the subsistence of known forms in the knower; all forms that flow are united in that from which they derive; everything that derives from some origin, is united in that origin. Berthold's elegant mosaic certainly reveals a strong affinity of the metaphysics of fluxus developed by Avicebron, based on the overflowing of forms, with the essential causality theorised by Dietrich of Freiberg. Compared to Dietrich's formulation, however, Avicebron seems to explicate more clearly the relationship between identity and difference established across the various ranks of reality, precisely because, according to Avicebron's doctrine, what flows is not the same essence, but rather, as we have seen, the virtus Dei and radii et vires of simple substances, which thus avoids the theoretical possibility of "a night in which all cows are black". ${ }^{37}$ Berthold himself explicitly links the dialectic of identity-difference with the doctrine of essential causality when tracing the structure of the last part of his commentary in Prop. 18:

Circa propositum tria faciam, quia primo ponam omnis aliis esse derivantis duplicem considerationem et ex hoc identitatis et diversitatis eius ad ea, quae tradit derivationem recipientibus, rationem, secundo addam praedictis multiplicem probationem, tertio ex praemissis ostendam propositi intentionem. ${ }^{38}$

It is therefore worthwhile exploring Avicebron's contribution to the doctrine of the essential cause, which seems to be linked to the metaphysics of the flow, that is, to clarify what is communicated from the first Creator to the lowest realities. This theme is taken up in Prop. 172, to which we now turn.

As previously shown, according to the intention expressed by Berthold in the Tabula contentorum, his commentary on Prop. 172 is dedicated to the definition of an essential cause. He skillfully interweaves large excerpts from chapters 6, 22, 23, and 24 of Dietrich's De cognitione entium separatorum and Avicebron's Fons vitae. The result is a presentation of the theory of essential causation that is apparently faithful to Dietrich's intentions, but in fact turns out to be an original interpretation of it. Let us discuss this in detail. 
Berthold aims at three objectives: to demonstrate that each intellectus in $a c t u$ is an essential cause, to describe its conditions, and to show that each essential cause contains its own effects. In doing this, Berthold constructs an argument taken from chapter 6 of De cognitione entium separatorum, in which Dietrich intends to demonstrate that angels (one of the levels of the universe described in section 2 of this article) are not essential causes. Dietrich states that each active substance acts in a manner corresponding to its own nature: therefore, some will act intellectually, others spiritually, and still others bodily. Among these, intellectual substances are those that act more eminently than the others because they are intellects by essence and, accordingly, their action is their essence (intelligendo agunt). As shown in section 2, to act according to the essence itself is the criterion that determines the hierarchical order of the four maneries and, therefore, distinguishes, Dietrich writes, the essential cause from the accidental cause: "est autem proprium et per se causae essentialis per suam essentiam causare. Et in hoc distinguitur a causa accidentali”. 39

"Omnis autem substantia activa elicit suam propriam actionem modo sibi proprio, id est secundum modum ipsius substantiae; unde aliter exerunt suas actiones intellectualia, aliter spiritualia et aliter corporalia, inter quae tria intellectualia, quae sunt intellectus per essentiam, altissimo modo agunt, quia intelligendo agunt," ut inferius apparebit, "et sic non agunt nisi per suas essentias," "et in hoc distinguuntur a causis" substantialibus, quales sunt animae caelorum cum suis corporibus, et "a causis accidentalibus, sive tales sint removens prohibens sive sint accidentales, quod vestiantur aliquibus accidentibus, quae sint sibi ratio agendi, ut calor igni." 40

Thanks to the precise editorial work of Jeck and Tautz, it is possible to reconstruct Berthold's intervention in this passage. In the midst of a literal quotation from Dietrich's text, Berthold introduces a significant variation: intellects by essence, which are essential causes, are distinguished not only from accidental causes (as Dietrich remarks), but also from substantial causes, which Berthold explicitly states - are the celestial souls with their own bodies ("'et in hoc distinguuntur a causis' substantialibus, quales sunt animae caelorum cum suis corporibus"). This is a relevant statement, because according to Dietrich, even celestial souls are essential causes. Dietrich himself makes a difference between essential causes, substantial causes, and accidental causes (see for example chapter 75 of De cognitione), and Berthold himself is fully aware of 
this (see for example his comment on Prop. ${ }_{7} \mathrm{C}$ ). But the point is that here Berthold does not quote chapter 75 of De cognitione, although he knows it, but the chapter in which Dietrich speaks about the status of angels. Berthold's intervention is clearly deliberate and, in my opinion, has only one meaning: heavenly souls are not intellectus in actu per essentiam and consequently are not essential causes.

As for accidental causes, Berthold adds that their manner of action is in a sense similar to the motion or power to cause essentially, which is (following Dietrich again) nothing other than a "flow of essential power flowing essentially into something else":

Dico autem "ratio agendi" non tantum "continuandi virtutem causae" ad "suum passum, qualia sunt accidentia" "corporis caelestis," quibus "virtus eius continuatur ad passa, puta motus et lumen, quibus mediantibus" virtus caeli continuatur inferioribus passivis; cui quasi consimilis est motus seu "causandi virtus essentialis, qui non est nisi defluxio virtutis essentialis essentialiter fluentis in aliud." 41

At this point, Berthold attaches a long passage from Avicebron's Fons vitae, already quoted above in section 1 , which states again that it is not the essences that flow, but rather their rays that spread usque infinitum because of their containment (continentia) in the first fluxus, which flows from the Will, that is - Berthold explains - the prime bonum:

Et hoc est, quod dicit Avencebrol libro III, cap. 52: "Essentiae substantiarum simplicium non sunt defluxae, sed vires earum et radii haec sunt, quae defluunt et effunduntur eo, quod essentiae uniuscuiusque harum substantiarum finitae sunt et terminatae" et "non extensae usque in infinitum, sed radii earum fluunt ab illis et excedunt terminos suos et limites propter continentiam earum sub primo fluxu, qui effluit a voluntate," scilicet prime boni, "sicut lumen, quod effluit a sole in aerem, quia hoc lumen excedit terminos solis et extenditur per aerem." 42

Then Berthold refers back to Dietrich's De cognitione and lists the five characteristics of an essential cause, already analysed above in section 2. Here

41 Berthold of Moosburg, Expositio, 172A, p. 121, 1. 29-34, citing Dietrich of Freiberg, De cognitione, 6.3, p. 173, l. 98-105.

42 Berthold of Moosburg, Expositio, 172A, p. 121, l. 35-41, citing Avicebron, Fons vitae, lib. III, c. $5^{2}$, p. $196,1.5^{-12}$. 
once again he introduces a slight but important modification to the Dietrich's text. While Dietrich affirms that the five characteristics listed are proper (conveniunt) to the separate substances, i.e. God and intelligences, in addition to heavenly souls, and, incidenter, also to the agent intellect, ${ }^{43}$ Berthold limits the range of the entities that merit the status of an essential cause by restricting it to omni intellectui, and thus excluding de facto God and heavenly souls. ${ }^{44}$

As previously shown, according to Berthold, God (prime Deus) is beyond the intellect. ${ }^{45}$ In agreement with Avicebron, Berthold argues that what is truly knowable by human beings is rather the voluntas Dei, which he identifies with Proclus' prime bonum. Voluntas in the Fons vitae represents not only the connection between the (unknowable) God and universe, but it is also the last level of reality that can be known, precisely because of its effects that are spread throughout the universe, all the way to composite realities, which include the human being.

As argued in section 1, Avicebron interprets the activity of simple substances (intellects) as the result of their desire to imitate the action of the primus factor, which bestows (largitur) the forms close to it (apud se) through the voluntas, its manifestation. This means that the factor primus is always beyond all its manifestation and that it is the voluntas that constitutes the primary outflowing, from which the outflow of the intelligences derives.

In the context of Berthold's commentary, Avicebron's theory of flux is easily assimilated to Dionysius' idea of the superessential Good, which is separated from all things (ab omnibus segregatum), but also at the same time is in all things (in omnibus). ${ }^{46}$ According to Dionysius, God moves out of himself to establish his effects because of his amorous goodness (bonitas amativa). In the same way, Berthold states in his commentary on Prop. 175, every essential cause redounds outside itself and is in a certain sense outside itself. In this process "every intellectual nature is elevated above nature properly speaking and reaches the likeness of the primarily Good" ("omnis intellectualis natura elevatur super naturam proprie dictam et accedit ad similitudinem prime boni”). Amor (love) is thus an act of will, which is the perfection of every intellectual

\footnotetext{
43 Dietrich of Freiberg, De cognitione, 23.6, p. 187, 1. 108-109.

44 Berthold of Moosburg, Expositio, 172B, p. 122, 1. 76-77.

45 See also Berthold of Moosburg, Expositio, 115E, p. 55, l. 175-177: Haec Dionysius. Ex his satis apparet de prime Dei supersubstantialitate. Cum ergo sit superens et ens sit super vitam et haec super intellectum per 101, patet prime Deum simpliciter esse supersubstantialem, supervitalem et superintellectum.

46 Berthold of Moosburg, Expositio, 175A, p. 146, l. 17.
} 
nature. It follows that Berthold calls the will of the separate intelligences "the communication of divine goodness", which is "intrinsic to their essence". ${ }^{47}$

Evidently influenced by Avicebron's theory on voluntas, Berthold emphasizes the role of the will in the process of emanation, deducing 1) that the bonum desires and loves intellectually and 2) that in the communication of the divine good, one acts neither for necessitatem coactionis nor for necessitatem naturae, but rather for an act of freedom. ${ }^{48}$

This assumption becomes clearer when Berthold compares two models of emanation in $175 \mathrm{~B}: 49$ one attributed to Avicenna and Algazel (imitator eius), the other to Avicebron and Plato.

According to the authority of the former, the intellectus universaliter agens acts by actively understanding (active intelligendo), that is, by emitting lower separate intelligences (intelligentias emittendo) as well as the various orders of intelligences that exist within the souls and celestial bodies.

According to the authority of Avicebron and Plato, instead, the intellectus in actu per essentiam produces entities not only by thinking (intelligendo), but rather (sed magis) by willing (volendo)..$^{50}$ This means that the activity of intellect derives ex intuitu voluntatis and it is therefore subjected to the superessential Will. ${ }^{51}$ As for Avicebron also for Berthold the submission of intelligences to the first cause is the result of the desire to imitate the voluntary activity of the divine will. For both thinkers, therefore, "the cosmic process is not a necessary and impersonal flow or radiation of all things from the First Principle" (as stated by Avicenna), but rather the outcome "of God's creative will."52

47 E. King, "Berthold of Moosburg on Intellect and the One of the Soul", in Dionysius 36(2018), p. 184-199, in particular p. 199.

48 Berthold of Moosburg, Expositio, 175A, p. 147, 1. 33-37: Ex hoc enim duo consequuntur ipsam voluntatem, unum in se, scilicet quod bonum proprium et eius communionem desiderat et amat amore intellectuali, secundum, quod in talis boni redundantis communione non agit necessitate coactionis, sed nec proprie necessitate naturae, sed voluntatis libertate, quae bene stat cum immutabilitatis necessitate.

49 Berthold of Moosburg, Expositio, 175B, p. 147, l. 6o-p. 149, l. 115.

50 Berthold of Moosburg, Expositio, 175B, p. 149, 1. 110-115: Hucusque positio Avicennae. Alii vero sunt, qui dicunt intellectum in actu per essentiam non solum intelligendo, sed magis volendo instituere ea, quae sunt'. Cui positioni videtur consentire Plato in Timaeo libro I, ubi dicit: "Voluntatem Dei originem certissimam rerum si quis ponat, recte" "consentiam", et Avencebrol libro V cap. 17, ubi dicit: "Plato consideravit, quod formae fiunt in intelligentia ex intuitu voluntatis, et fiunt in anima universali ex intuitu intelligentiae universalis". Sicut igitur simpliciter prima causa agit et creat omnia volendo, ita etiam omnis alia causa essentialis et praecipue intellectus per essentiam in causando primo se nititur conformare.

$5^{1}$ Cf. King, "Berthold of Moosburg", p. 199.

$5^{2}$ J.A. Weisheipl, "Albertus Magnus and Universal Hylomorphism: Avicebron. A Note on Thirteenth-Century Augustinianism", in The Southwestern Journal of Philosophy 10/3 (1979), p. 239-26o, at p. 249. 
In my view, the existence of celestial souls and bodies as essential causes is proven by the model of Avicenna and Algazel, but not by Avicebron's model, which seems to be the one closest to Berthold's intentions. This may be the reason for Berthold's significant silence on the question of heavenly souls in Prop. 172, a silence that cannot be attributed to a mere synthesis of Dietrich's theory, but rather to Berthold's specific interpretation of essential causality. His clear preference for Avicebron's emanative model seems also to be confirmed by the overlap between the voluntas and prime bonum, which emphasizes the role of the Dionysian notion of bonitas amativa, to the detriment of Avicennian intellectualism.

One can thus conclude that, combining Dietrich's authority with that of Avicebron, Berthold proposes his own interpretation of essential causality, according to which only intellectus in actu per essentiam are causae essentiales.

At the same time, however, the metaphysics of the flow outlined by Avicebron seems to diverge from what Proclus affirms in Propositions 72, 7 and 18, namely, that every intellectus in actu per essentiam presupposes the subject in which it acts and that it touches (tangit) substantially (substantialiter), which suggests an almost 'physical' contact between the various hierarchical orders.

Omnis intellectus in actu per essentiam et praesupponit subiectum suum, in quod agit, praeelaboratum ab omnibus causalioribus se principiis agentibus, per 72, et est simul cum eo et tangit ipsum substantialiter, quia, quidquid in eo est, totum est substantia simplex intellectualis, et per consequens similem substantiam sibi causat, cum omne agens agat sibi simile, licet effectus deficiat in esse a sua per se causa, per 7 et 18 et omnis talis coexistentia per essentiam sit causalis active et passive, ut inferius apparebit. ${ }^{53}$

How can this be possible if it is not the substances that flow, but rather their rays and forces, i.e. their qualities? To solve this apparent contradiction Berthold turns again to the authority of Avicebron to show that, if it is true that radii et vires are what flow, they nevertheless emanate from a substantial cause, and thus they transmit the same substantiality from higher to lower. It can therefore be said, briefly, that these radii et vires of intellectus in actu per essentiam are of the same essence as this intellect that diffuses itself intentionally. They therefore have a connection both with the essence of the intellect from which they come, and with the essences of the things caused, which are of the same essence as the emanating intellect, but differ according to the mode of being,

Berthold of Moosburg, Expositio, 172E, p. 124, l. 139-46. 
as shown in the commentary to Prop. 18. This explanation, Berthold emphasizes, derives from the text of Avicebron, which seems therefore perfectly consonant with Dietrich's theory, even if with some correction or clarification.

5 Conclusion

Even after an analysis only of Berthold's commentary on Propositions 18 and 172, some conclusions can be drawn:

1) The pivotal role of the Fons vitae in Berthold's Expositio is confirmed. Berthold extensively quotes Avicebron at first hand and without the mediation of Thomas of York's Sapientiale.

2) Without diminishing the contribution of Albert the Great and Ulrich of Strassburg, Avicebron's contribution is particularly significant in relation to the theory of essential causality, as documented by Berthold's Tabula contentorum.

3) Berthold uses Avicebron to resolve some ambiguities in the formulation of Dietrich's theory of essential causality: on the one hand, to safeguard God's perfect transcendence and, on the other, to ensure the perfect unity and intelligibility of the created universe.

4) Berthold restricts the status of essential cause to the intellectus in actu per esentiam, excluding God and the celestial souls, and fully shares Avicebron's theory that it is radii et vires of simple substances that overflow and not their essences.

5) To this end Berthold associates the voluntas of the Fons vitae to the Proclean prime bonum as the source of the flow of forms spreading through all the universe as far as contracted and determined entities. In this way he emphasizes the voluntary activity of God and of the intelligences, to detriment of Avicennian intellectualism.

7) Thanks to this chain of forms, the human being is able to go back from composite substances to the first source, which however is not God himself, but rather the voluntas Dei.

\section{Bibliography}

\section{Primary Sources}

Avicebron, Fonte della vita, ed. M. Benedetto, Milano, Bompiani, 2007.

Avicebron, Fons vitae. Translationem ex Arabico in Latinum, ed. C. Baeumker, Münster, Aschendorff, 1892-1895. 
Avicebron, La source de vie. Livre III. La demonstration de l'existance des substances simples, trad. par F. Brunner, Paris, Vrin, 1950.

Berthold of Moosburg, Expositio super Elementationem theologicam Procli. Prologus, Propositiones 1-13, eds M.R. Pagnoni-Sturlese, L. Sturlese, Hamburg, Meiner, 1984.

Berthold of Moosburg, Expositio super Elementationem theologicam Procli.Propositiones 14-34, eds L. Sturlese, M.R. Pagnoni-Sturlese, B. Mojsisch, Hamburg, Meiner, 1986.

Berthold of Moosburg, Expositio super Elementationem theologicam Procli.Propositiones 35-65, ed. A. Sannino, Hamburg, Meiner, 2001.

Berthold of Moosburg, Expositio super Elementationem theologicam Procli.Propositiones 66-107, ed. I. Zavattero, Hamburg, Meiner, 2003.

Berthold of Moosburg, Expositio super Elementationem theologicam Procli. Propositiones 108-135, ed. F. Retucci, Hamburg, Meiner, 2011.

Berthold of Moosburg, Expositio super Elementationem theologicam Procli.Propositiones 136-159, ed. F. Retucci, Hamburg, Meiner, 2007.

Berthold of Moosburg, Expositio super Elementationem theologicam Procli.Propositiones 160-183, eds U.R. Jeck, I.J. Tautz, Hamburg, Meiner, 2003.

Berthold of Moosburg, Expositio super Elementationem theologicam Procli.Propositiones 184-211, ed. L. Sturlese, Hamburg, Meiner, 2014.

Berthold of Moosburg, Tabula contentorum in Expositione super Elementationem theologicam Procli, ed. A. Beccarisi, Pisa, Scuola Normale Superiore, 2000.

Dietrich of Freiberg, Schriften zur Naturphilosophie und Metaphysik, eds J.-D. Cavigioli et al., Hamburg, Meiner, 1983.

Dietrich of Freiberg, Schriften zur Intellekttheorie, ed. B. Mojsisch, Hamburg, Meiner, 1977.

Hegel, G.W.F., Phänomenologie des Geistes, Hamburg, Meiner, $195^{2}$.

\section{Secondary Sources}

Beccarisi, A., "Zwischen Averroes, Avicenna und Avicebron. Meister Eckhart und die Noetik im Islam und Judentum", in C. Büchner, M. Enders, D. Mieth (eds), Meister Eckhart - interreligiös, Stuttgart, Kohlhammer, 2016 = Meister Eckhart Jahrbuch 10 (2016), p. 223-240.

Benedetto, B., Saggio introduttivo, in Avicebron, Fonte della vita, ed. M. Benedetto, Milano, Bompiani, 2016.

Bray, N., "Magis videtur fuisse Stoicus. La ricezione di Avicebron in Alberto il Grande", in A. Beccarisi, A. Palazzo (eds), Flumen Sapientiae. Studi sul pensiero medievale, Roma, Aracne Editrice, 2019, p. 79-98.

Bray, N., "Eckhart e la riforma filosofica dell'umiltà cristiana", in Giornale critico della filosofia italiana (forthcoming). 
Brunner, F., "Maître Eckhart et Avicébron", in J. Jolivet, Z. Kaluza, A. de Libera (eds), Lectionum Varietates. Hommage à Paul Vignaux (1904-1987), Paris, Vrin, 1991, p. 133-154.

Brunner, F., "Création et emanation. Fragment de philosophie compare", in F. Brunner, Métaphysique d'Ibn Gabirol et de la tradition platonicienne, Aldershot, Ashgate/ Variorum, 1997, p. 33-63.

Calma, D., Le poids de la citation. Étude sur les sources arabes et grecques dans l'œuvre de Dietrich de Freiberg, Freiburg, Academic Press, 2011.

Flasch, K., Dietrich von Freiberg. Philosophie, Theologie, Naturforschung um 1300, Frankfurt, Klostermann, 2007.

Flasch, K., "Einleitung", in Dietrich of Freiberg, Schriften zur Naturphilosophie und Metaphysik, p. XV-XXXI.

Führer, M., Gersh, S., "Dietrich of Freiberg and Berthold of Moosburg”, in S. Gersh (ed.), Interpreting Proclus: From Antiquity to the Renaissance, Cambridge, Cambridge University Press, 2014, p. 299-317.

King, E., Supersapientia. A Study of the Expositio super Elementationem theologicam Procli of Berthold von Moosburg, PhD diss, University of Cambridge, 2016.

King, E., "Berthold of Moosburg on Intellect and the One of the Soul", in Dionysius 36(2018), p. 184-199.

McGinn, B., "Sapientia Judaeorum: the Role of Jewish Philosophers in Some Scholastic Thinkers", in R. J. Bast, A.C. Gow (eds), Continuity and Change. The Harvest of Late Medieval and Reformation History, Leiden, Brill, 200o, p. 206-228.

McGinn, B., "Ibn Gabirol: The Sage among the Schoolmen", in L. E. Goodman (ed.), Neoplatonism and Jewish Thought, Albany, NY, sUNY Press, 1992, p. 77-109.

Mojsisch, B., "Causa essentialis bei Dietrich von Freiberg und Meister Eckhart", in K. Flasch (ed.), Von Meister Dietrich zu Meister Eckhart, Hamburg, Meiner, 1984, p. 106-114.

Mojsisch, B., "Die Theorie des Intellekts bei Berthold von Moosburg. Zur Proklosrezeption im Mittelalter", in Th. Kobusch, B. Mojsisch, O. Summerell (eds), Selbst - Singularität - Subjektivität: Vom Neuplatonismus zum Deutschen Idealismus, Amsterdam, Grüner, 2002, p. 175-184.

Pagnoni-Sturlese, M.R., “À propos du néoplatonisme d'Albert le Grand: Aventures et mésaventures de quelques textes d'Albert dans le Commentaire sur Proclus de Berthold de Moosburg", in Archives de Philosophie 43(1980), p. 635-654.

Pagnoni-Sturlese, M.R., "Filosofia della natura e filosofia dell'intelleto in Teodorico di Freiberg e Bertoldo di Moosburg", in K. Flasch (ed.), Von Meister Dietrich zu Meister Eckhart, Hamburg, Meiner, 1984, p. 115-127.

Palazzo, A., "Eckhart's Islamic and Jewish Sources: Avicenna, Avicebron, and Averroes", in J.M. Hackett (ed.), A Companion to Meister Eckhart, Leiden, Brill, 2013, p. 253-298. 
Pessin, S., "Solomon Ibn Gabirol (Avicebron)", in Stanford Encyclopedia of Philosophy https://plato.stanford.edu/entries/ibn-gabirol/.

Porreca, D., "Hermes Trismegistus in Thomas of York: A 13th-Century Witness to the Prominence of an Ancient Sage", in Archives d'histoire doctrinale et littéraire du Moyen Age 72(2005), p. 147-275.

Retucci, F., "Magister Thomas Anglicus minor", in Berthold of Moosburg, Expositio super Elementationem theologicam Procli, Hamburg, Meiner, 2007, p. xxiii-xxxix.

Retucci, F., "Magister Thomas Anglicus minor: Tommaso di York fonte della Expositio super Elementationem theologicam Procli", in Quaderni di Noctua 5(2020), p. 1-41.

Strauss, Z., "Meister Eckhart reading Ibn Gabirol's Fons vitae", in Y. Meyrav (ed.), Yearbook of the Maimonides Centre for Advanced Studies, Berlin / Boston, De Gruyter, 2019, p. 65-100.

Sturlese, L., "Il De animatione caeli di Teodorico di Freiberg", in R. Creytens, P. Künzle (eds), Xenia medii aevi historiam illustrantia oblata Thomae Kaeppeli O.P., Roma, Edizioni di storia e letteratura, 1978, p. 175-247.

Sturlese, L., Homo divinus. Philosophische Projekte in Deutschland zwischen Meister Eckhart und Heinrich Seuse, Stuttgart, Kohlhammer, 2007.

Suarez-Nani, T., "Substances séparées, intelligences et anges chez Thierry de Freiberg", in K.-H. Kandler, B. Mojsisch, F.-B. Stammkötter (eds), Dietrich von Freiberg. Neue Perspektiven seiner Philosophie, Theologie und Naturwissenschaft, Amsterdam, Grüner, 1999, p. 49-67.

Weisheipl, J.A., "Albertus Magnus and Universal Hylomorphism: Avicebron. A Note on Thirteenth-Century Augustinianism", in The Southwestern Journal of Philosophy 10/3(1979), p. 239-26o.

Zavattero, I., "Berthold of Moosburg”, in H. Lagerlund (ed.), Encyclopedia of Medieval Philosophy, Dordrecht, Springer, 2011, p. 163-165. 